\title{
Metode Isolasi dan Identifikasi Struktur Senyawa Organik Bahan Alam
}

\author{
Sri Atun \\ Jurusan Pendidikan Kimia, FMIPA, Universitas Negeri Yogyakarta \\ Email : Atun_1210@yahoo.com
}

\begin{abstract}
Abstrak: Beberapa penelitian etnomedika yang tercatat dalam dokumen kuno dari beberapa wilayah Indonesia menunjukkan adanya beberapa jenis tumbuhan yang dapat digunakan sebagai obat untuk menyembuhkan berbagai penyakit, maupun dapat diterapkan pada benda yang mengalami permasalahan akibat aktivitas suatu organisme. Senyawa bioaktif dapat berkhasiat sebagai anti bakteri, anti jamur, anti serangga dan lain-lain. Namun demikian, agar tumbuhan tersebut dapat dikembangkan dan dilestarikan perlu dilakukan penelitian yang berkelanjutan, sehingga dapat diketahui jenis senyawa bioaktifnya. Untuk mengetahui kandungan senyawa aktif dari tumbuhan perlu dilakukan isolasi, sehingga diperoleh senyawa murni. Selanjutnya dari senyawa murni yang diperoleh belum memiliki makna apabila belum diketahui struktur molekulnya. Dalam artikel ini akan dibahas mengenai metode isolasi dan penentuan struktur senyawa alam.
\end{abstract}

Kata kunci: Isolasi, Identifikasi, Senyawa bioaktif

Abstract: Some ethno-medical studies, which have been written in ancient documents from several regions in Indonesia, shows that there are several types of plant used as medicines to cure diseases as well as to be applied in an object that has problem with organism's growth. The bioactive compound could be used as anti-bacteria, anti-fungi, anti-insect, etc. Nevertheless, continuous study is needed to investigate the type of its bioactive compound. Thus, the plant could be developed and preserved. In identifying the active compound from a plant, isolation is needed to gain pure compound. The pure compound has no meaning if its molecular structure has not been identified. The article discuss about isolation methodology and determination on the structure of natural compound.

Keywords: Isolation, Identification, Bioactive compound

\section{Pendahuluan}

Indonesia termasuk salah satu negara "megadiversity" yang kaya keanekaragaman hayati. Di dunia terdapat kurang lebih 250.000 jenis tumbuhan tinggi, dan lebih dari $60 \%$ dari jumlah ini merupakan tumbuhan tropika. Diperkirakan sekitar 30.000 tumbuhan ditemukan di dalam hutan hujan tropika, dan sekitar 1.260 spesies di antaranya diketahui berkhasiat sebagai obat. Namun, baru sekitar 180 spesies yang telah digunakan untuk berbagai keperluan industri obat dan jamu, dan baru beberapa spesies saja yang telah dibudidayakan secara intensif [1]. Keanekaragaman hayati Indonesia tersebut terutama tersebar di setiap pulau besar, seperti Kalimantan, Papua, Sumatra dan Jawa. Di samping itu terdapat organisme lain seperti jamur maupun mikroba yang belum banyak tersentuh oleh peneliti. Keanekaragaman hayati tersebut merupakan sumber biomolekul senyawa-senyawa organik yang tidak terbatas jumlahnya [1].

Sejak dahulu kala, nenek moyang kita telah mengetahui sifat-sifat yang berguna dari berbagai jenis tumbuhan untuk mengobati penyakit, pembunuh jamur maupun pengawet kayu sebagai bahan bangunan maupun yang lainnya. Sebagian informasi tersebut ada yang tercatat dalam dokumen kuno yang berasal dari beberapa wilayah Indonesia, namun ada juga yang hanya sebagai cerita dari mulut ke mulut. Namun demikian, agar tumbuhan tersebut dapat dikembangkan dan dilestarikan perlu dilakukan penelitian yang berkelanjutan, sehingga dapat diketahui jenis senyawa bioaktifnya serta khasiatnya untuk mengobati penyakit-penyakit tersebut maupun sebagai bahan pengawet kayu maupun yang lainnya [2-4].

Penerapan bahan aktif dari tumbuhan tidak terbatas pada pengobatan terhadap penyakit manusia. Khasiat bioaktif tersebut selain sebagai obat pada penyakit manusia juga dapat diterapkan pada benda yang mengalami permasalahan akibat aktivitas suatu organisme. Senyawa bioaktif dapat berkhasiat sebagai anti bakteri, anti jamur, anti serangga dan lainlain. Salah satu material yang terancam pelapukan akibat aktivitas organisme adalah benda-benda cagar budaya. Cagar budaya merupakan tinggalan budaya yang memiliki nilai penting sehingga perlu untuk 
dilestarikan, umumnya sudah berumur tua dan telah lapuk. Pelestarian cagar budaya dapat dilakukan dengan mengendalikan faktor-faktor perusaknya, dengan cara-cara konservasi menggunakan berbagai bahan termasuk bahan tradisional. Masyarakat tradisional selain meninggalkan cagar budaya dalam bentuk benda, juga mewariskan berbagai praktek yang bertujuan memelihara atau mengawetkan benda-benda tersebut. Cara-cara tradisional tersebut menggunakan bahan-bahan alam termasuk dari tumbuh-tumbuhan. Penelitian mengenai isolasi senyawa aktif pada tumbuhan yang digunakan sebagai bahan konservan tradisional pada cagar budaya juga penting untuk dilakukan.

Perkembangan dalam penelitian bahan alam mengalami kemajuan yang semakin cepat dengan ditemukannya teknik-teknik pemisahan secara kromatografi dan penentuan struktur molekul secara spektroskopi pada pertengahan abad ke-20. Dengan menggunakan metode tersebut beberapa struktur senyawa bioaktif berhasil ditemukan, misalnya penemuan alkaloid seperti vinblastin dan vinkristin dari tumbuhan Catharanthus roseus (tapak dara) sebagai obat kanker. Demikian juga penemuan taksol dari tumbuhan Taxus brevifolia, serta taxoter hasil modifikasinya yang dapat digunakan sebagai obat kanker kandungan. Hal ini mendorong perusahaanperusahaan farmasi untuk mengeksplorasi senyawasenyawa bioaktif dari tumbuhan sebagai lead compounds penemuan obat baru[3-5].

Di Amerika Serikat terdapat sekitar 45 macam obat penting berasal dari tumbuhan obat tropika, 14

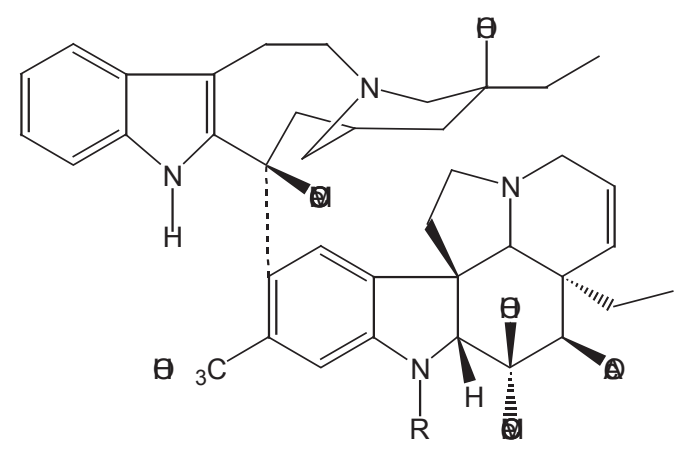

$\mathrm{R}=\mathrm{Me}$, Vinblastin

$\mathrm{R}=\mathrm{CHO}$, Vinkristin
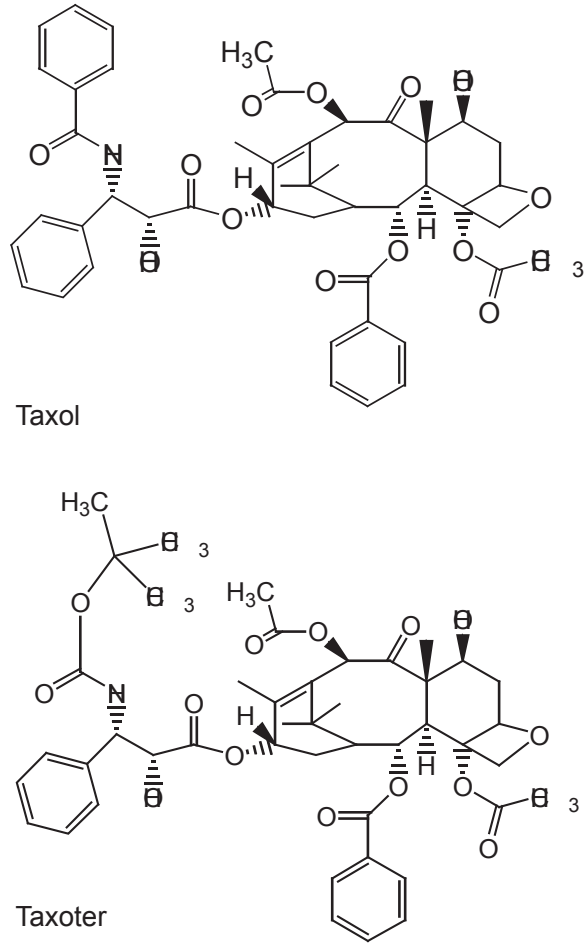

spesies berasal dari Indonesia, di antaranya obat anti kanker vinblastin dan vinkristine dan obat hipertensi reserpine yang berasal dari pulai pandak (Rauvolfia serpentina). Pada tahun 1983-1994 lebih dari 40\% obat baru yang disetujui oleh FDA adalah senyawa alam, dan saat ini lebih dari 30\% bahan obat yang beredar diperdagangan juga berasal dari senyawa alam. Dengan demikian, di masa yang akan datang akan lebih banyak lagi ditemukan obat-obat baru yang berasal dari alam, baik dari tumbuhan, hewan, maupun organism[5].

Hasil metabolisme suatu organisme hidup (tumbuhan, hewan, mikroorganisme) berupa metabolit primer dan sekunder. Senyawa metabolit primer umumnya sama untuk setiap organisme, terdiri dari molekul-molekul besar seperti polisakarida, protein, asam nukleat, dan lemak. Fungsi senyawa metabolit primer adalah sebagai sumber energi untuk kelangsungan hidup organisme atau sebagai cadangan energi bagi organisme itu sendiri. Metabolit sekunder berupa molekul-molekul kecil, bersifat spesifik, artinya tidak semua organisme mengandung senyawa sejenis, mempunyai struktur yang bervariasi, setiap senyawa memiliki fungsi atau peranan yang berbedabeda[6].

Pada umumnya senyawa metabolit sekunder berfungsi untuk mempertahankan diri atau untuk 
mempertahankan eksistensinya di lingkungan tempatnya berada. Dalam perkembangannya senyawa metabolit sekunder tersebut dipelajari dalam disiplin ilmu tersendiri yaitu kimia bahan alam (natural product chemistry). Metabolit sekunder merupakan biomolekul yang dapat digunakan sebagai lead compounds dalam penemuan dan pengembangan obat-obat baru.

\section{Metode Isolasi Senyawa Organik Bahan Alam}

\section{Ekstraksi}

Senyawa metabolit sekunder biasanya terdapat dalam organisme dalam jumlah yang sangat sedikit. Oleh karena itu biasanya dalam proses isolasi dimulai dari sampel yang jumlahnya banyak, minimal $2 \mathrm{~kg}$ sampel kering yang sudah dihaluskan. Pekerjaan isolasi membutuhkan ketrampilan dan pengalaman dalam memadukan berbagai teknik pemisahan. Untuk mendapatkan senyawa murni biasanya peneliti menggunakan beberapa teknik ekstraksi dan kromatografi. Teknik ekstraksi senyawa organik bahan alam yang biasa digunakan antara lain maserasi, perkolasi, infudasi, dan sokhletasi. Sedangkan teknik kromatografi yang biasanya digunakan antara lain kromatografi lapis tipis (KLT), kromatografi kolom vakum (KVC), kromatografi kolom gravitasi (KKG), dan kromatotron (Centrifugal Chromatography). Pemilihan jenis metode biasanya dilakukan berdasarkan pengalaman peneliti maupun hasil penelitian yang telah dilaporkan sebelumnya[7-10].

Langkah pertama yang biasanya dilakukan dalam isolasi senyawa organik bahan alam adalah ekstraksi sampel menggunakan pelarut organik. Ada beberapa metode ekstraksi sampel bahan alam, antara lain maserasi, infusdasi, digesti, perkolasi dan soxletasi. Maserasi merupakan teknik ekstraksi dari sampel padat menggunakan pelarut tertentu biasanya digunakan metanol atau etanol. Metanol memiliki kelebihan memiliki titik didih yang lebih rendah sehingga mudah diuapkan pada suhu yang lebih rendah, tetapi bersifat lebih toksik. Sedangkan etanol memiliki kelemahan memiliki titik didih yang relatif tinggi sehingga lebih sulit diuapkan, tetapi relatif tidak toksik dibanding metanol. Proses maserasi dilakukan selama waktu tertentu dengan sesekali diaduk, biasanya dibutuhkan waktu 1-6 hari. Selain metanol atau etanol pelarut yang lain yang biasa digunakan antaralain aseton, klroform, atau sesuai dengan kebutuhan. Setelah waktu tertentu ekstrak yang disebut maserat dipisahkan dengan cara penyaringan. Maserasi biasanya dilakukan pengulangan dengan penambahan pelarut setelah dilakukan penyaringan maserat yang pertama yang disebut remaserasi. Remaserasi biasanya dilakukan tiga kali atau sampai senyawa yang diinginkan dalam sampel benar-benar sudah habis. Apabila dalam proses maserasi dilakukan pengadukan terus menerus maka disebut juga dengan maserasi kinetik. Sedangkan apabila dalam maserasi kinetik tersebut dilakukan di atas suhu kamar, biasanya 40-50 oC disebut digesti. Cara yang biasa dilakukan adalah dengan menempatkan sejumlah bahan ditempatkan pada wadah tertutup, ditambah dengan pelarut dengan perbandingan kira-kira 1:7, atau sedikitnya semua sampel tercelup. Diamkan selama 1-6 hari pada suhu kamar dan terlindung dari cahaya dengan sesekali diaduk. Setelah itu, cairan dipisahkan, buang bagian yang mengendap. Pada saat proses perendaman senyawa organik yang terkandung dalam sampel berdifusi melewati dinding sel untuk melarutkan konstituen dalam sel dan juga memacu larutan dalam sel untuk berdifusi keluar. Sistem yang digunakan dalam metode ini adalah sistem statis, kecuali saat digojog, proses ekstraksi berjalan dengan difusi molekuler, sehingga proses ini berlangsung secara perlahan. Setelah ekstraksi selesai, residu dari sampel harus dipisahkan dengan pelarut dengan didekantir atau disaring. Maserasi dengan pengulangan (remaserasi) akan lebih efisien dari pada hanya sekali saja, hal ini terjadi karena ada kemungkinan sejumlah besar komponen aktif masih tertinggal dalam proses maserasi yang pertama. Sejumlah filtrat (maserat) dari hasil pengulangan maserasi selanjutnya dicampur dan dipekatkan.

Infusdasi merupakan metode ekstraksi dengan pelarut air. Pada waktu proses infusdasi berlangsung, temperatur pelarut air harus mencapai suhu $90^{\circ} \mathrm{C}$ selama 15 menit. Rasio berat bahan dan air adalah 1 : 10, artinya jika berat bahan 100 gr maka volume air sebagai pelarut adalah $1000 \mathrm{ml}$. Cara yang biasa dilakukan adalah serbuk bahan dipanaskan dalam 
panci dengan air secukupnya selama 15 menit terhitung mulai suhu mencapai $90^{\circ} \mathrm{C}$ sambil sekalisekali diaduk. Saring selagi panas melalui kain flanel, tambahkan air panas secukupnya melalui ampas hingga diperoleh volume yang diinginkan. Apabila bahan mengandung minyak atsiri, penyaringan dilakukan setelah dingin.

Dekoksi merupakan proses ekstraksi yang mirip dengan proses infusdasi, hanya saja infus yang dibuat membutuhkan waktu lebih lama ( $\geq 30$ menit) dan suhu pelarut sama dengan titik didih air. Caranya, serbuk bahan ditambah air dengan rasio $1: 10$, panaskan dalam panci enamel atau panci stainless steel selama 30 menit. Bahan sesekali sambil diaduk. Saring pada kondisi panas melalui kain flanel, tambahkan air panas secukupnya melalui ampas hingga diperoleh volume yang diinginkan.

Perkolasi adalah proses ekstraksi dengan pelarut yang dialirkan melalui kolom perkolator yang diisi dengan serbuk bahan atau sampel, dan ekstraknya dikeluarkan melalui keran secara perlahan. Secara umum proses perkolasi ini dilakukan pada temperatur ruang. Parameter berhentinya penambahan pelarut adalah perkolat sudah tidak mengandung komponen yang akan diambil. Pengamatan secara fisik pada ekstraksi bahan alam terlihat tetesan perkolat sudah tidak berwarna. Caranya, serbuk bahan dibasahi dengan pelarut yang sesuai dan ditempatkan pada bejana perkolator. Bagian bawah bejana diberi sekat berpori untuk menahan serbuk. Cairan pelarut dialirkan dari atas kebawah melalui serbuk tersebut. Cairan pelarut akan melarutkan zat aktif dalam sel-sel yang dilalui sampai keadaan jenuh.

Soxkletasi merupakan proses ekstraksi dengan menggunakan pelarut yang selalu baru yang umumnya dilakukan dengan alat khusus soxklet sehingga terjadi ekstraksi konstan dengan adanya pendingin balik. Caranya, serbuk bahan ditempatkan pada selongsong dengan pembungkus kertas saring, lalu ditempatkan pada alat soxklet yang telah dipasang labu dibawahnya. Tambahkan pelarut sebanyak 2 kali sirkulasi. Pasang pendingin balik, panaskan labu, ekstraksi berlangsung minimal 3 jam dengan interval sirkulasi kira-kira 15 menit.

\section{Kromatografi}

Langkah berikutnya setelah diperoleh ekstrak dalam isolasi senyawa organik bahan alam adalah pemisahan komponen-komponen yang terdapat dalam ekstrak tersebut. Teknik yang banyak digunakan adalah kromatografi. Kromatografi adalah teknik pemisahan campuran berdasarkan perbedaan kecepatan perambatan komponen dalam medium tertentu. Pada kromatografi, komponenkomponennya akan dipisahkan antara dua buah fase yaitu fase diam dan fase gerak. Fase diam akan menahan komponen campuran sedangkan fase gerak akan melarutkan zat komponen campuran. Komponen yang mudah tertahan pada fase diam akan tertinggal. Sedangkan komponen yang mudah larut dalam fase gerak akan bergerak lebih cepat. Beberapa teknik kromatografi yang banyak digunakan antara lain kromatografi lapis tipis (KLT), kromatografi kolom vakum (KVC), kromatografi kolom gravitasi (KG), dan kromatotron.

Kromatografi lapis tipis adalah suatu teknik pemisahan komponen-komponen campuran suatu senyawa yang melibatkan partisi suatu senyawa di antara padatan penyerap (adsorbent, fasa diam) yang dilapiskan pada pelat kaca atau aluminium dengan suatu pelarut (fasa gerak) yang mengalir melewati adsorbent (padatan penyerap). Pengaliran pelarut dikenal sebagai proses pengembangan oleh pelarut (elusi). KLT mempunyai peranan penting dalam pemisahan senyawa organik maupun senyawa anorganik, karena relatif sederhana dan kecepatan analisisnya. Di dalam analisis dengan KLT, sampel dalam jumlah yang sangat kecil ditotolkan menggunakan pipa kapiler di atas permukaan pelat tipis fasa diam (adsorbent), kemudian pelat diletakkan dengan tegak dalam bejana pengembang yang berisi sedikit pelarut pengembang. Oleh aksi kapiler, pelarut mengembang naik sepanjang permukaan lapisan pelat dan membawa komponen-komponen yang terdapat dalam sampel.

Pemilihan fasa gerak yang tepat merupakan langkah yang sangat penting untuk keberhasilan analisis dengan KLT. Umumnya fasa gerak dalam KLT ditemukan dengan coba-coba dan jarang sekali yang didasarkan pada pengetahuan yang mendalam. 
Sifat-sifat pelarut pengembang juga merupakan faktor dominan dalam penentuan mobilitas komponenkomponen campuran. Umumnya kemampuan suatu pelarut pengembang untuk menggerakkan senyawa pada suatu adsorben berhubungan dengan polaritas pelarut.

Kemampuan ini disebut kekuatan elusi, dan urutan kekuatan elusi beberapa pelarut yaitu air $>$ metanol $>$ etanol $>$ aseton $>$ etil asetat $>$ kloroform $>$ dietil eter $>$ metilen diklorida $>$ benzena $>$ toluena $>$ karbon tetraklorida $>$ heksan $>$ petroleum eter. Identifikasi senyawa yang telah terpisah pada lapisan tipis dapat dilakukan dengan menggunakan reaksi penampak noda maupun dideteksi menggunakan lampu UV (254 atau $356 \mathrm{~nm}$ ) untuk senyawa-senyawa yang dapat menyerap warna.

Kromatografi vakum cair digunakan untuk fraksinasi ekstrak total secara cepat. Teknik ini dapat dilakukan dengan menggunakan kolom kromatografi yang dihubungkan dengan pompa vakum, dengan isian kolom silika gel untuk TLC (10 -40 $\mu \mathrm{m})$. Sebagai eluen digunakan campuran pelarut dari yang non polar secara bertahap ke yang polar. Hasil pemisahan dari kromatografi vakum cair adalah fraksi-fraksi yang dapat dikelompokkan menjadi kelompok senyawa non polar, semi polar, dan polar.

Kromatografi vakum cair merupakan modifikasi dari kromatografi kolom gravitasi. Metode ini lebih banyak digunakan untuk fraksinasi sampel dalam jumlah besar (10-50 g). Kolom yang digunakan biasanya terbuat dari gelas dengan lapisan berpori pada bagian bawah. Ukuran kolom bervariasi tergantung ukurannya. Kolom disambungkan dengan penampung eluen yang dihubungkan dengan pompa vakum. Pompa vakum akan menghisap eluen dalam kolom, sehingga proses pemisahan berlangsung lebih cepat. Penggunaan tekanan dimaksudkan agar laju aliran eluen meningkat sehingga meminimalkan terjadinya proses difusi karena ukuran silika gel yang biasanya digunakan pada lapisan kromatografi KLT sebagai fasa diam dalam kolom yang halus yaitu 200-400 mesh. Kolom yang digunakan berukuran lebih pendek dari pada kolom kromatografi gravitasi dengan diameter yang lebih besar $(5-10 \mathrm{~cm})$. Kolom KVC dikemas kering dalam keadaan vakum agar diperoleh kerapatan kemasan maksimum. Sampel yang akan dipisahkan biasanya sudah diadsorbsikan ke dalam silika kasar terlebih dahulu (ukuran silika kasar 30-70 mesh) agar pemisahannya lebih teratur dan menghindari sampel kangsung menerobos ke dinding kaca tanpa melewati adsorben terlebih dahulu, yang dapat berakibat gagalnya proses pemisahan. Pelarut yang kepolarannya rendah dituangkan ke permukaan penyerap yang sebelumnya sudah dimasukkan sampel. Kolom dihisap perlahan-lahan ke dalam kemasan dengan memvakumkannya. Kolom dielusi dengan campuran pelarut yang cocok, mulai dengan pelarut yang kepolarannya rendah lalu kepolaran ditingkatkan perlahan-lahan. Kolom dihisap sampai kering pada setiap pengumpulan fraksi, sehingga kromatografi vakum cair disebut juga kolom fraksinasi.

Kromatografi gravitasi dapat digunakan untuk pemisahan dan pemurnian senyawa yang telah difraksinasi menggunakan kromatografi vakum cair. Teknik ini dapat dilakukan dengan kolom diameter ukuran 1-3 cm dan panjang kolom $50 \mathrm{~cm}$. Sebagai adsorben digunakan silika gel GF 60 (200-400 mesh). Tinggi adsorben yang biasa digunakan berkisar 15-20 $\mathrm{cm}$. Eluen yang digunakan menggunakan campuran

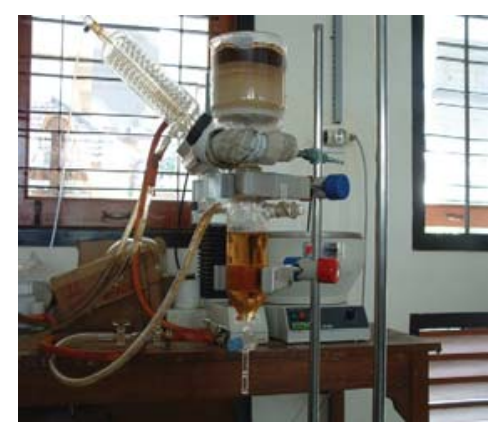

A

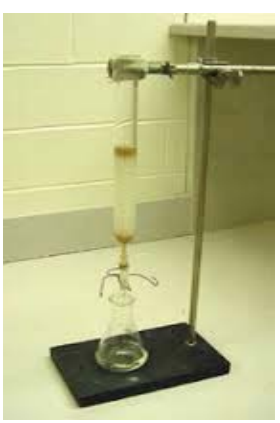

$\mathrm{B}$

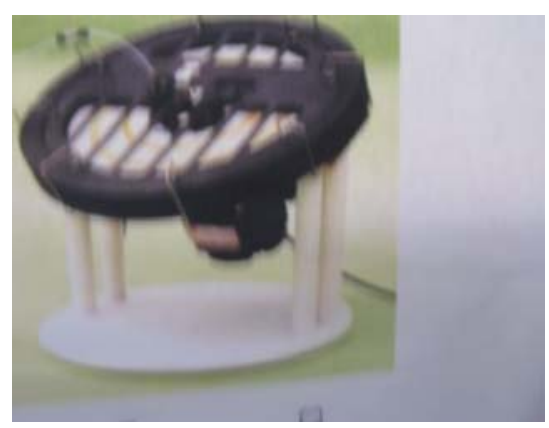

C

Gambar 1. Beberapa teknik kromatografi KVC (A); KG (B); kromatotron (C) 
pelarut polar dan non polar dengan perbandingan yang sesuai. Pemisahan dengan kromatografi kolom gravitasi biasanya akan diperoleh hasil yang baik apabila digunakan campuran pelarut yang dapat memisahkan komponen pada Rf kurang dari 0,3 pada uji coba dengan KLT.

Kromatotron atau sentrifugal kromatografi merupakan kromatografi menggunakan alat yang disebut kromatotron, teknik pemisahannya menggunakan gaya sentrifugal dan gravitasi. Dalam teknik ini digunakan silika gel for TLC yang berflourecent. Prinsip pemisahan dengan kromatotron sama dengan kromatografi yang lainnya, tetapi pemisahan akan berlangsung lebih cepat, oleh karena ada gaya sentrifugal yang akan mempercepat proses penyerapan pelarut yang membawa komponen yang dipisahkan.

Penggunaan gabungan sedikitnya tiga macam teknik kromatografi di atas sudah dapat digunakan untuk memisahkan dan memurnikan senyawa organik bahan alam. Namun diperlukan ketrampilan dalam penggunaan serta ketepatan dalam memilih jenis kromatografi, serta ketepatan pemilihan eluen yang sesuai. Beberapa teknik kromatografi tersebut

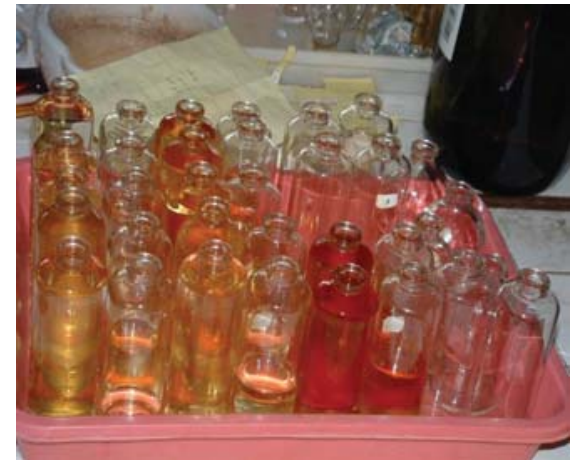

A

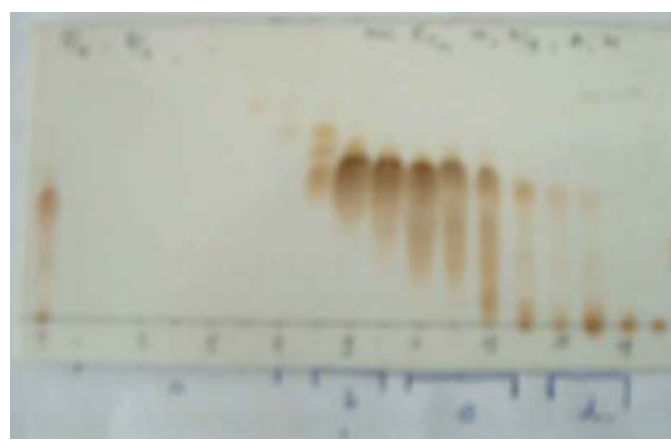

C dapat dilihat dalam gambar 1.

Hasil pemisahan secara kromatografi selanjutnya diperoleh fraksi-fraksi yang ditampung dalam botol atau tabung dan dianalisis secara kromatografi lapis tipis (KLT), yang biasa disebut kromatogram. Kromatogram yang diperoleh selanjutnya dianalisis dengan lampu UV pada panjang gelombang 254 atau $356 \mathrm{~nm}$ atau disemprot dengan reagen warna. Salah satu reagent warna yang banyak digunakan antara lain serium sulfat yang dapat mendeteksi hampir semua senyawa bahan alam, maupun reagen yang khusus seperti Lieberman Burchard untuk mendeteksi terpenoid dan steroid. Fraksi-fraksi yang telah dinalisis secara KLT selanjutnya dikelompokkan berdasarkan jumlah senyawa maupun Rfnya yang sama digabungkan untuk dianalisis lebih lanjut. Pemisahan dianggap cukup apabila sudah diperoleh fraksi yang menunjukkan noda tunggal pada beberapa uji KLT dengan menggunakan berbagai variasi eluen yang berbeda. Adanya noda tunggal pada beberapa uji KLT tersebut menunjukkan bahwa sudah diperoleh senyawa dengan tingkat kemurnian tinggi.

\section{Identifikasi Senyawa Organik Bahan Alam}

1. Menggunakan Pereaksi Warna

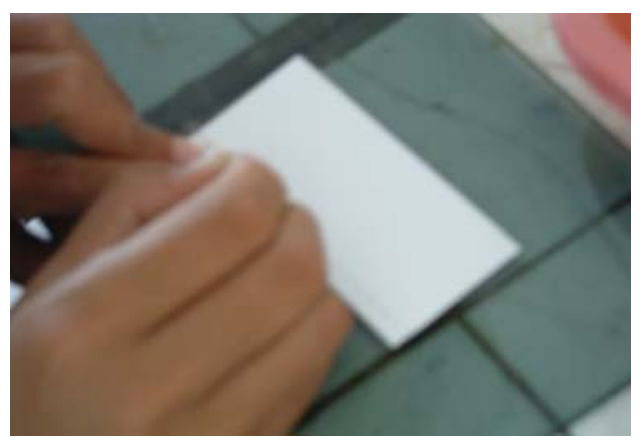

B

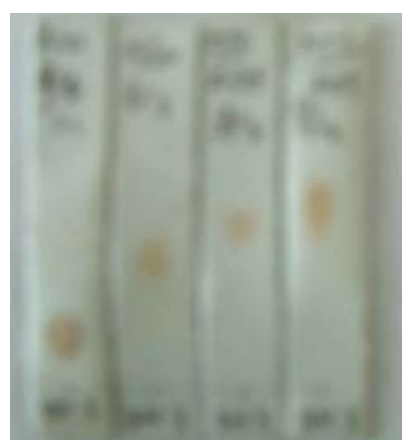

D

Gambar 2. Fraksi-fraksi hasil pemisahan (A); analisis dengan KLT (B); kromatogram (C); dan kromatogram senyawa yang sudah murni pada berbagai campuran pelarut (D) 
Pengujian kandungan kimia secara kualitatif terhadap ekstrak atau senyawa murni dapat dilakukan secara sederhana untuk menentukan golongan senyawa yang diperoleh. Secara rinci beberapa pengujian sederhana yang dapat dilakukan adalah sebagai berikut :

a. Uji sterol dan triterpenoids: ekstrak metanol dilarutkan dalam kloroform, disaring dan filtrat diuji untuk sterol dan triterpenoids

1) Uji Salkowski : Beberapa tetes asam sulfat pekat ditambahkan ke larutan kloroform dan diamati untuk warna merah di lapisan bawah untuk sterol dan warna kuning keemasan menunjukkan adanya Triterpenoid.

2) Libermann Buchard test: Beberapa tetesan hidrida asetat ditambahkan ke dalam larutan kloroform, kocok dan teteskan $1 \mathrm{ml}$ asam sulfat pekat dengan hati-hati ditambahkan dari sisi tabung reaksi. Jika berwarna coklat kemerahan menunjukkan adanya sterol dan cincin merah menunjukkan adanya triterpenoid.

b. Uji alkaloid: 0,5 g ekstrak diencerkan secara terpisah untuk $10 \mathrm{ml}$ dengan alkohol asam, direbus dan disaring. $5 \mathrm{ml}$ filtrat ditambahkan $2 \mathrm{ml}$ encer amonia. $5 \mathrm{ml}$ kloroform ditambahkan dan kocok dengan lembut untuk mengekstrak alkaloid. Lapisan kloroform diekstraksi dengan $10 \mathrm{ml}$ asam asetat, dan dibagi dalam 3 bagian, dan diuji sebagai berikut:

1) Uji Dragendroff : (kalium nitrat- bismut): Beberapa tetes larutan Dragendroff ditambahkan ke dalam larutan kloroform, endapan coklat kemerahan menunjukkan adanya alkaloid.

2) Uji Mayer : (Kalium iodida- merkuri) : Beberapa tetes reagent Mayer ditambahkan ke dalam larutan kloroform, jika terbentuk endapan putih menunjukkan adanya alkaloid.

3) Uji Wagner : (Yodium- kalium iodida dalam)

: Beberapa tetes larutan Wagner ditambahkan ke dalam larutan kloroform, jika terbentuk endapan coklat menunjukkan adanya alkaloid.

c. Uji Saponin: Foam Test : Untuk $0.5 \mathrm{~g}$ ekstrak ditambahkan $5 \mathrm{ml}$ air suling dalam tabung reaksi. Larutan dikocok dengan kuat dan diamati terbentuknya buih yang stabil. Buih itu dicampur dengan 3 tetes minyak zaitun dan dikocok dengan kuat setelah itu diamati untuk pembentukan emulsi.

d. Uji flavonoids: Sampel dilarutkan dalam pelarut yang sesuai, sebanyak $2 \mathrm{ml}$ dimasukkan ke dalam tabung reaksi dan tambahkan beberapa tetes larutan $\mathrm{FeCl3}$, apabila terbentuk warna ungu menunjukkan positif terhadap flavonoid.

\section{Identifikasi struktur molekul menggunakan metode spektroskopi}

Elusidasi struktur molekul senyawa organik merupakan tahapan terpenting dari penggunaan analisis spektroskopi modern. Dalam elusidasi struktur molekul untuk menentukan struktur senyawa hasil sintesis jauh lebih mudah dari pada elusidasi senyawa hasil isolasi. Oleh karena analisis struktur molekul dari hasil sintesis sudah dapat diprediksi struktur molekulnya berdasarkan reaktan yang digunakan serta mekanisme reaksinya. Sedangkan dalam elusidasi struktur molekul senyawa hasil isolasi relatif lebih rumit, karena struktur molekul yang sangat banyak kemungkinannya. Untuk mempermudah analisis struktur senyawa hasil isolasi biasanya diperlukan pengetahuan sebelumnya mengenai keragaman struktur senyawa yang telah diperoleh dari tumbuhan yang memiliki kekerabatan yang dekat, misalnya merupakan tumbuhan dalam genus atau famili yang sama. Biasanya senyawa yang ditemukan dari tumbuhan dalam satu genus atau famili memiliki hubungan kekerabatan senyawa metabolit sekundernya. Selanjutnya sebagai tambahan informasi untuk mempermudah dalam analisis struktur senyawa hasil isolasi juga diperlukan data sifat fisik, seperti kelarutan, titik leleh, maupun jenis pelarut yang digunakan dalam proses pemisahan.

Metode spektroskopi yang biasanya digunakan untuk identifikasi struktur yang biasa digunakan antara lain spektroskopi ultraviolet (UV), infra merah (IR), NMR (Nuclear magnet resonance), dan massa. Spektroskopi UV untuk identifikasi adanya gugus kromofor (fenolik; ikatan rangkap; dll) , spektroskopi IR untuk identifikasi adanya gugus fungsional ( hidroksil; aromatik; karbonil; dsb), 
spektroskopi NMR (1H dan $13 \mathrm{C}$ ), 1H NMR untuk menentukan jumlah dan lingkungan proton (atom $\mathrm{H}$ dalam senyawa), 13 C NMR untuk menentukan jumlah atom karbon dalam senyawa, sedangkan untuk menentukan massa atom relatif ( $\mathrm{Mr}$ ) digunakan MS[10-13].

Namun demikian, dalam elusidasi struktur molekul yang kompleks baik senyawa hasil sintesis maupun isolasi tidak cukup hanya menggunakan data spektroskopi UV, IR, 1H NMR, 13C NMR, dan MS, tetapi masih diperlukan data spektroskopi NMR dua dimensi seperti HMQC (Heteronuclear Multiple Quantum Coherence), HMBC (Heteronuclear Multiple Bond Connectivity), 1H-1H COSY (Homonuclear Correlated Spectroscopy), maupun NOESY (Nuclear Overhauser Effect Spectroscopy). Spektroskopi dua dimensi HMQC dapat digunakan untuk mengetahui proton-karbon dengan jarak satu ikatan, sehingga dapat diketahui karbon yang mengikat proton dan karbon yang tidak mengikat proton. Spektroskopi HMBC dapat mengetahui proton-karbon dengan jarak dua atau tiga ikatan, sehingga dapat digunakan untuk mengetahui karbonkarbon tetangga yang memiliki jarak dua sampai tiga ikatan dengan suatu proton tertentu. Untuk mengetahui proton-proton yang berdampingan digunakan data spektroskopi 1H-1H COSY, sedangkan untuk mengetahui struktur konfigurasi cis-trans digunakan data spektroskopi NOESY. Dengan menggunakan data spektroskopi dua dimensi elusidasi struktur menjadi semakin mudah dan secara tepat dapat menentukan kerangka struktur molekul senyawa organik serumit apapun.

Dalam elusidasi struktur molekul biasanya dimulai dari data yang paling sederhana, misalnya spektroskopi UV (kalau ada), selanjutnya IR, analisis data 1H NMR dan 13C NMR, dengan memperhatikan data massa molekul dari spektroskopi MS. Dari datadata tersebut biasanya sudah dapat memprediksi struktur kerangka senyawa yang dianalisis, ada kemungkinan memiliki beberapa alternatif struktur.
Selanjutnya untuk menentukan struktur yang paling sesuai dibuktikan dengan data fragmentasi dari spektroskopi MS[10-13].

\section{Penutup}

Sejalan dengan keberadaan organisme di alam yang tidak terbatas jumlahnya, maka topik penelitian bahan alam juga tidak akan pernah habis. Penelitian bahan alam biasanya dimulai dari ekstraksi, isolasi dengan metode kromatografi sehingga diperoleh senyawa murni, identifikasi struktur dari senyawa murni yang diperoleh dengan metode spektroskopi, dilanjutkan dengan uji aktivitas biologi baik dari senyawa murni ataupun ekstrak kasarnya. Setelah diketahui struktur molekulnya biasanya juga dilanjutkan dengan modifikasi struktur untuk mendapatkan senyawa dengan aktivitas dan kestabilan yang diinginkan. Di samping itu, dengan kemajuan bidang bioteknologi, dapat juga dilakukan peningkatan kualitas tumbuhan atau organisme melalui kultur jaringan, maupun tumbuhan transgenik yang tentunya juga akan menghasilkan berbagai jenis senyawa metabolit sekunder baru yang beraneka ragam dan mungkin juga dengan struktur molekul yang berbeda dengan yang ditemukan dari tumbuhan awalnya.

Penentuan struktur molekul merupakan bagian yang tidak dapat dipisahkan dari isolasi senyawa kimia bahan alam. Senyawa hasil isolasi belum memiliki makna jika belum diketahui struktur molekulnya. Metode penentuan struktur senyawa organik yang banyak digunakan adalah metode spektroskopi, yang meliputi UV, IR, NMR (1H dan 13C), dan MS. Untuk menentukan struktur senyawa organik yang relatif sederhana metode tersebut sudah cukup memadai, namun untuk senyawa dengan kerangka karbon yang cukup kompleks penggunaan NMR dua dimensi yang meliputi HMQC, HMBC, COSY, dan NOESY mutlak diperlukan[7-13]. 


\section{Daftar Pustaka}

Syamsul A.A., E.H. Hakim, L.D. Juliawati, L. Makmur, S. Kusuma, Y.M. Syah, (1995), Eksplorasi kimia tumbuhan hutan tropis Indonesia : beberapa data mikromolekuler tumbuhan Lauraceae sebagai komplemen etnobotani, Prosiding Seminar Etnobotani Tanggal 24-25 Januari 1995, Fakultas Biologi UGM, Yogyakarta, 8 -12.

Dalimarta, S. (2003), Atlas tumbuhan obat Indonesia, jilid 2, Trubus Agriwidya

Dharma AP., (1985), Tanaman Obat Tradisional Indonesia, P.N. Balai Pustaka, Jakarta, hal. 265-266.

Heyne K. (1987), Tumbuban berguna Indonesia, Badan Litbang Kehutanan, Jakarta, jilid III, $1390-1443$.

Grabley R.T., (1999), Drug discovery from nature, Springer-Verlag, Berlin

Cannell, Richard J.P. (1998). Natural Products Isolation Methods in Biotechnology ; 4. Totowa : Humana Press.
Hostettman, K., Hostettman, M., \& Marston, A. (1986). Cara Kromatografi Preparatif. (Alih bahasa: Kosasih P). Bandung: ITB.

Harborne, J.B. (2006). Metode Fitokimia: Penuntun Cara Modern Menganalisis Tumbuhan (alih bahasa: Kosasib Padmawinata \& Iwang Soediro). Bandung : Penerbit ITB.

Sudjadi. 1988. Metode Pemisahan. Yogyakarta: KANISIUS. Hardjono Sastrohamidjojo. (2005). Kromatografi. Yogyakarta : Liberty

Silverstein R.M.; Webster F.X., 1998, Spectrometric Identification of Organic Compounds, sixth edition,New York: John Wiley \& Sons, Inc.

Harjono Sastrohamidjojo. (2007). Spektroskopi. Yogyakarta : Penerbit Liberty.

Pavia, D.L, Lampman G.M, Kriz G.S, 2007, Introduction to spectroscopy, Australia : Brook/Cole. 